\title{
Recenzja
}

\section{Andrzej Bisztyga, Oddzialywanie Europejskiej Konwencji Praw Człowieka na wewnętrzny porządek prawny Zjednoczonego Królestwa, Górnośląska Wyższa Szkoła Handlowa im. W. Korfantego, Katowice 2008, ss. 376}

Książka Andrzeja Bisztygi pt. Oddziaływanie Europejskiej Konwencji Praw Człowieka na wewnętrzny porządek prawny Zjednoczonego Królestwa zasługuje na szczególną uwagę z kilku względów. Po pierwsze niezwykle rzadko ukazują się w Polsce monografie traktujące o systemie konstytucyjnym Zjednoczonego Królestwa Wielkiej Brytanii i Irlandii Północnej. Wprawdzie $\mathrm{w}$ ostatnim czasie $\mathrm{w}$ tym względzie nastąpiła pewna poprawa ${ }^{1}$, to i tak dorobek polskiej doktryny prawa konstytucyjnego dotyczący Wielkiej Brytanii wydaje się być ubogi, szczególnie na tle innych demokracji Zachodu. Drugim argumentem, wypływającym po części z pierwszego jest to, że recenzowana monografia daje możliwość bliższego zapoznania się z praktycznym funkcjonowaniem systemu prawnego opartego o common law. Po trzecie, problematyka będąca przedmiotem badań autora pozwala choć w części zapoznać się z wybranymi elementami poważnej reformy konstytucyjnej wprowadzonej przez laburzystów po wygranych wyborach do Izby Gmin w 1997 r. Skala zmian, które zaszły w brytyjskim systemie konstytucyjnym pod rządami Partii Pracy w latach 1997 - 2010 jest na tyle znacząca, że w przypadku kontynentalnego modelu konstytucji moglibyśmy mówić o zasadniczej jej rewizji. Czwartym argumentem do którego można się odwołać jest to, iż obecnie w doktrynie prawa konstytucyjnego bardzo aktualnym problemem jest wpływ umów międzynarodowych (aktów

W tym miejscu odnotować należy takie pozycje jak: S. Kubas, Parlament Szkocki. Dewolucja - wyzwanie dla Zjednoczonego Królestwa, Warszawa 2004; P. Mikuli, Zasada podziatu władz a ustrój brytyjski, Warszawa 2006; P. Biskup, Prawno-polityczna ewolucja brytyjskiej doktryny suwerenności, Warszawa 2007; P. Sarnecki, System konstytucyjny Zjednoczonego Królestwa Wielkiej Brytanii i Irlandii Pótnocnej, Warszawa 2009; Ustawy ustrojowe Zjednoczonego Królestwa Wielkiej Brytanii i Irlandii Pótnocnej, tłum. S. Kubas, wstęp P. Sarnecki, Warszawa 2010. 
ponadpaństwowych) na wewnętrzny porządek prawny. Przedstawiona przez A. Bisztygę analiza przypadku może być podstawą do poszukiwania jeszcze doskonalszych instrumentów dla implementacji tego typu umów międzynarodowych, a Europejskiej Konwencji Praw Człowieka w szczególności.

Recenzowana książka przedstawia w sposób ewolucyjny oddziaływanie Europejskiej Konwencji Praw Człowieka na porządek prawny Zjednoczonego Królestwa. Autor dla swojej analizy przyjął kryterium historyczne. Taki wybór wydaje się w pełni uzasadniony, pozwala bowiem obok analizy funkcjonowania Konwencji we współczesnym porządku konstytucyjnoprawnym Wielkiej Brytanii, ukazać także złożony proces ewolucji jej oddziaływania w ostatnim sześćdziesięcioleciu.

Poprawna jest struktura pracy. Nie chodzi przy tym wyłącznie o kolejność i zawartość rozdziałów, ale przede wszystkim o to, że praca zawiera zarówno warstwę teoretyczną, jak i poddaje analizie praktyczną stronę oddziaływania Konwencji. Autor zgromadził materiał w czterech rozdziałach, rozbitych na mniejsze części, poprzedzonych warsztatowym wstępem, w którym wyjaśniono tytuł rozprawy, uzasadniono jego wybór, przedstawiono cele pracy, jej tezy oraz zasadnicze pytania badawcze, na które autor poszukiwał odpowiedzi w toku prowadzonego wywodu. We wstępie nakreślono także ramy chronologiczne i rzeczowe, ukazano strukturę pracy, wreszcie scharakteryzowano źródła i literaturę przedmiotu.

W rozdziale pierwszym przedstawiono genezę Europejskiej Konwencji Praw Człowieka oraz szeroko omówiono wkład Wielkiej Brytanii w prace nad powstaniem konwencji. Autor słusznie zauważa, że Wielka Brytanii $\mathrm{z}$ jednej strony chciała aktywnie uczestniczyć w procesie tworzenia europejskiego traktatu dotyczącego praw człowieka, tak aby nie znaleźć się poza głównym nurtem kształtowania norm w tym zakresie. Przyjmowała przy tym postawę aktywną, a czasem wprost przewodnią, co pozwalał na swoisty pilotaż i kontrolę procesu tworzenia Konwencji. Z drugiej jednak strony Zjednoczone Królestwo od samego początku prac nie było zainteresowane związaniem się traktatem o prawach człowieka (s. 47). Autor w swojej analizie wskazuje na wiele przykładów działań dyplomacji brytyjskiej, które zmierzały do osłabienia wymowy traktatu (s. 60-75). Tłem takiej postawy - jak słusznie zauważa A. Bisztyga - było pokutujące po dziś dzień przekonanie wśród polityków i prawników brytyjskich, o wyższości wyspiarskich rozwiązań w dziedzinie praw człowieka nad sposobami ich ochrony w syste- 
mach kontynentalnych, czy też w prawie międzynarodowym. W tym też należy doszukiwać się źródeł zdystansowanego podejścia Zjednoczonego Królestwa do europejskiego systemu ochrony praw człowieka sensu largo. Ten „instytucjonalny sceptycyzm” widoczny jest też w całej jaskrawości w stosunku Wielkiej Brytanii do procesu integracji europejskiej, ze szczególnym uwzględnieniem Karty Praw Podstawowych. Rozważania w tym względzie mogły być pogłębione. W tym miejscu należy wyrazić pewien żal, że autor tak rygorystycznie trzymał się przedmiotowo zakreślonych ram badawczych.

Rozdział drugi koncentruje się na problematyce związanej z miejscem Konwencji w porządku prawnym Zjednoczonego Królestwa między przystąpieniem do Konwencji a jej inkorporacją. Autor w bardzo ciekawy sposób przedstawia w nim ponad trzydziestoletni okres „zmagania się” brytyjskiego systemu prawnego z sytuacją uznania jurysdykcji Konwencji na terytorium Królestwa. Podstawą analizy dotyczącej wpływu orzecznictwa Europejskiego Trybunału Praw Człowieka na brytyjski porządek prawny jest charakterystyka specyficznego rozumienia konstytucji i jej roli w państwie. Zasadniczą, wynikającą z tych rozważań tezą jest konstatacja, że cechą charakterystyczną konstytucji Zjednoczonego Królestwa jest „brak katalogu wolności i praw jednostki, który byłby wyposażony w nadrzędną - nadstawowa moc prawną" (s. 97). Jak słusznie zauważa Autor, specyfika konstytucji brytyjskiej powoduje, że wolności i prawa jednostki nie mają szansy na nadanie im rangi nadustawowej. Uważane są one za element konstytucji materialnej, ale wypracowane są jedynie w orzecznictwie sądowym lub wyrażone w aktach rangi ustawowej. Wartą podkreślenia zaletą tej części rozdziału jest przybliżenie terminu „residual rights”, którego zdefiniowanie jest konieczne dla zrozumienia filozofii tradycyjnego systemu ochrony wolności i praw w brytyjskim systemie prawnym. Termin ten tłumaczyć należy jako „prawa pozostałe”. Takie jego rozumienie wynika z koncepcji traktowania praw i wolności jednostki jako domeny swobody jednostki rozumianej jako ogół uprawnień jednostki przysługujących jej po uwzględnieniu wszelkich ograniczeń prawnych oraz ingerencji w sferę aktywności jednostki ze strony podmiotów publicznych i prywatnych. Innymi słowy, jak wyjaśnia Au- 
tor „chodziło o negatywne ujmowanie wolności i praw jednostki, stanowiące pozostałość po zsumowaniu wszelkich dotyczących ich ograniczeń” (s. 102)2.

W odrębnej części rozdziału drugiego A. Bisztyga dokonuje przeglądu szeregu praw i wolności w kontekście obowiązywania Konwencji (s. 138170). Podstawą przeprowadzonej w rozdziale analizy są licznie przytaczane orzeczenia sądów brytyjskich. Autor poddaje je własnym krytycznym ocenom i formułuje ciekawe wnioski. Dla przykładu można wskazać podrozdziały dotyczące m.in.: podsłuchu telefonicznego (s. 138-140), kar cielesnych w szkołach (s. 140-145), prawa osób pozbawionych wolności (s. 151155) czy praw pacjentów zakładów psychiatrycznych (s. 156-159). Osobną część tego rozdziału poświęcono wpływowi członkostwa Wielkiej Brytanii w EWG i związanymi z tym faktem konsekwencjami oddziaływania Konwencji na jej wewnętrzny porządek prawny (s. 170-181). Zgodzić należy się z postawioną przez Autora tezą, że przystąpienie Zjednoczonego Królestwa do EWG w 1973 roku było okolicznością o istotnym znaczeniu w procesie przybliżania Konwencji brytyjskiemu porządkowi prawnemu. Wywiązanie się ze zobowiązań wynikających z członkostwa w EWG powodowało bowiem, że Wielka Brytania musiała wprowadzić mechanizmy pozwalające na obowiązywanie prawa wspólnotowego, jak i oddziaływanie orzecznictwa Trybunału Sprawiedliwości Wspólnot Europejskich na wewnętrzny porządek prawny.

Trzeci rozdział poświęcony jest problematyce dotyczącej uchwalenia ustawy the Human Rights Act z 1998 r. Już w samym tytule rozdziału Autor słusznie wskazuje, że uchwalenie przedmiotowej ustawy traktować należy jako zmianę konstytucji Zjednoczonego Królestwa. Oczywiście można polemizować z przytoczonym w książce poglądem, który Autor wydaje się podzielać, że uchwalenie ustawy the Human Rights Act jest „najistotniejszą zmianą w prawie konstytucyjnym na przestrzeni kilku dekad” (s. 184), to z całą pewnością trzeba przyznać, że ustawa zrewolucjonizowała cały segment konstytucji materialnej dotyczący praw i wolności człowieka i obywatela, należący w nowożytnej tradycji konstytucyjnej do materii najważniejszej i najbardziej szanowanej.

2 Zob. szerzej: A. Zięba, Z zagadnień rezydualnej koncepcji praw i wolności obywatelskich, [w:] Prawa człowieka - Społeczeństwo obywatelskie - Państwo demokratyczne. Księga jubileuszowa dedykowana Profesorowi Pawłowi Sarneckiemu pod red. P. Tulei, M. Florczak-Wątor, S. Kubasa, Warszawa 2010, s. 117 i nast. 
W pierwszej części rozdziału trzeciego A. Bisztyga dokonuje ogólnej charakterystyki ustawy i jej znaczenia w brytyjskim systemie konstytucyjnym i prawnym. Zwraca uwagę, że ustawa włącza do brytyjskiego systemu prawa niemal cały katalog wolności i praw zawarty w Konwencji. Bardzo ważną okolicznością, słusznie podkreśloną przez autora, jest niekompletność inkorporacji. Dla przykładu art. 2 ust. 1 ustawy nakłada jedynie na sąd krajowy obowiązek wzięcia pod uwagę (must take into account) orzecznictwa Europejskiego Trybunału Praw Człowieka. Tak więc, w świetle doktryny prawa brytyjskiego, ustawa jest dla brytyjskich sądów wiążąca, a orzecznictwo Trybunału powinno być jedynie „wzięte pod uwagę” (s. 193). W dalszej części rozdziału poruszone są problemy sądowej wykładni ustawy w zgodzie z Konwencją, ze szczególnym podkreśleniem jej praktycznych aspektów oraz postępowanie przeciwko władzom publicznym.

W osobnych częściach rozdziału trzeciego Autor poświęca szczególną uwagę skomplikowanej kwestii sądowej deklaracji niezgodności ustaw z Konwencją i wynikających z tego faktu konsekwencji (s. 217-227), parlamentarnemu postępowaniu naprawczemu oraz udziałowi $\mathrm{w}$ tym procesie członków rządu (s. 228-237).

Rozdział czwarty zawiera analizę konstytucyjnych aspektów obowiązywania ustawy the Human Rights Act. Autor przedstawił w nim analizę dwóch głównych nurtów w brytyjskiej doktrynie prawa konstytucyjnego: inkorporacjonistycznego (s. 250-254) oraz demokracji partycypacyjnej (s. 254-259). Przedstawiciele pierwszego z nurtów, starają się nadać ustawie status podobny do statusu prawa wspólnotowego. Według nich sfera praw człowieka powinna być chroniona od wpływów świata polityki. Ich zdaniem sądy są najlepszym instrumentem służącym ochronie praw i wolności. Założenia nurtu demokracji partycypacyjnej stanowią w istocie odwrotność twierdzeń inkorporacjonistów. Uważają oni, że w pierwszej kolejności parlament, a jedynie uzupełniająco sąd, powinien kształtować status jednostki w państwie.

Osobną część rozdziału czwartego poświęcono wpływowi ustawy na relację między władzą ustawodawczą, wykonawczą i sądowniczą. Autor słusznie dowodzi tam, że w doktrynie prawa państw kultury common law coraz mocniejszy nacisk kładzie się na współpracę pomiędzy organami poszczególnych władz w celu osiągania zamierzonych celów konstytucyjnych. W dalszych rozważaniach Autor odnosi się także do wpływu ustawy na konstytucyjną rolę brytyjskich sądów i sędziów słusznie zauważając, że wejście w ży- 
cie przedmiotowej ustawy osłabiło znaczenie w brytyjskim porządku prawnym prawa tworzonego przez sędziów (judge made law) w zakresie wolności i praw człowieka i obywatela w Zjednoczonym Królestwie.

Książkę zamyka sprawnie napisane podsumowanie odnoszące się syntetycznie do wszystkich najważniejszych podnoszonych w pracy zagadnień, a uzupełnia „wykaz materiałów wykorzystanych w pracy”, będące dowodem na to w jak szerokim zakresie autor wykorzystał piśmiennictwo przedmiotu oraz orzecznictwo sądowe. Dodatkowym walorem godnym podkreślenia, jest zamieszczenie $w$ książce streszczeń obcojęzycznych (j. angielski, j. rosyjski).

W podsumowaniu należy podkreślić, że książka A. Bisztygi Oddziaływanie Europejskiej Konwencji Praw Człowieka na wewnętrzny porządek prawny Zjednoczonego Królestwa jest pozycją ważną dla nauki i praktyki. Zapełnia lukę w krajowej literaturze przedmiotu, wprowadzając do rodzimego obiegu naukowego nowe elementy pomocne w dobrym zrozumieniu specyfiki systemu konstytucyjnego Zjednoczonego Królestwa. Praca napisana została językiem przystępnym i komunikatywnym, nie tracąc przy tym nic ze swojej profesjonalnej wartości. Recenzowana pozycja warta jest poleceniu specjalistom z zakresu prawa konstytucyjnego, europejskiego i międzynarodowego. Z pewnością powinna też zainteresować wszystkich studiujących na kierunkach prawniczych i politologicznych oraz przedstawicieli innych dyscyplin naukowych zainteresowanych współczesną Wielką Brytanią.

Krzysztof Urbaniak (Uniwersytet A. Mickiewicza w Poznaniu) 